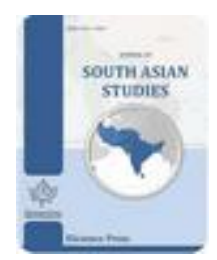

Available Online at EScience Press

Journal of South Asian Studies

ISSN: 2307-4000 (Online), 2308-7846 (Print)

https://esciencepress.net/journals/JSAS

\title{
IMPACT OF IRRIGATION CROPPING PATTERN: A CASE STUDY OF KETHEPALLI MANDAL NALGONDA DISTRICT
}

\author{
Yedavelli Saidulu* \\ Department of Geography, University College of Science, Osmania University, Hyderabad, India.
}

*Corresponding AuthorEmail ID: prabhu.eflu@gmail.com

\section{A B S T R A C T}

The present study is concerned with major crops, cropping patterns, area, production, and yield of major crops in both spatial and temporal aspects, and socioeconomic change due to agriculture, both irrigated and dryland agriculture in Kethepalli Mandal are part of Nalgonda district of Telangana State, India. The study intends first to identify the major crops and the cropping patterns of the district, by Mandals as well as overtime. Upon identification, an examination and analysis of the pattern of cropping and related aspects are attempted. The interpretation of the analysis is expected to yield an understanding of the development problems of, and prospects for, the irrigated and dryland farming of the district. The present research is introductory in that it introduces a broad overview of agriculture and global development perspectives, Indian agricultural sector, Indian and Telangana agriculture, and then introduces the problem of study, the schemes by the government, the objectives, the study area, the methodology, and the conclusion.

Keywords: Agricultural, Cropping pattern, soils, Geographical status, Irrigation.

\section{INTRODUCTION}

Agriculture is defined broadly and differently under different laws of the country, based on the purpose and objectives of respective Acts (for example, the government has introduced several acts and schemes for agricultural development. Examples Raythubandu, Raithubharosa, for acre government introduced rs 12000. This financial assistance becomes the backbone of farmers. It is an excellent encouragement to farmers, especially in this region. There are other acts also government introduced. The Agricultural Produce (Grading and Marketing) Act 1937, The State Agricultural Credit Corporation Act 1968, Urban Land Ceiling and Regulation Act 1976, National Bank for Agriculture and Rural Development Act 1981, Central Agricultural University Act 1992). 'Agricultural operations' include animal husbandry, dairy farming, pisciculture, and poultry farming. 'Agricultural produce' includes all produce of agriculture or horticulture and all articles of food or drink, wholly or partly manufactured from any such products and fleeces and the skins of animals (to name a few, Warehousing Corporation Act 1962, National Cooperative Development Corporation Act 1962). 'Agriculture purpose' on the other hand refers to tilling and cultivation for purposes of raising crops' The Millennium Development Goals (MDG) for the agricultural sector stipulated two major targets: one, the proportion of people whose income is less than one US dollar a day (or around Rs. 60 now) and, two, the proportion of people who suffer from hunger need to be reduced by half between 1990 and 2015. The two are very relevant and important for India, Telangana, Kethepalli Mandal, Nalgonda district, keeping in view nearly 60 percent of their populations depend on agriculture for their livelihoods. It is pertinent at this point to recall the focus of the World Development Report 2020 on 'Agriculture for Development' and the crucial role of governance in supporting the main elements of 'Agriculture for Development' agendas (Agriculture for Development, World Development Report 2020). 


\section{REVIEW OF LITERATURE}

Jacobvan Etten (2018) Are agricultural researchers working on the right crops to enable food and nutrition security under future climates? This study examined how crop-specific agricultural research investments can be prioritized to anticipate climate change impact on crops and to enable the production of more nutritious food. We used a simple crop modeling approach to derive expected future changes in regional climate suitability for crops. To determine if different starch-rich and pulse crops are currently under researched or over researched, we examined the global relation between crop-specific research output (number of publications) and the total nutrient output available for human consumption.

Our analysis shows that current research investments are mostly associated with the current energy output of crops. Other things equal, investment levels tend to be slightly lower for crops better adapted to future climates and tend to decrease as crop nutrient richness increases. Among starch-rich crops, maize, barley, and rice receive substantially more research investment than justified by their current nutrient output. Sweet potato, potato, and wheat show substantial current research deficits. Sweet potato is most strongly under researched in regions with improving climate suitability. For potatoes, research deficits occur in regions where these crops will experience less suitable climate conditions. For wheat, the deficits are distributed equally across regions with negative and positive climate effects. Three crops are significantly over-researched, namely maize, rice, and barley. Among pulses, cowpea, and lupin are generally over researched. Common bean is highly underresearched, but these deficits concentrate in areas where it will likely suffer from climate change. Lentil, broad bean, and chickpea are under researched, with deficits concentrating in regions where these crops will tend to benefit from future climates. Agricultural research investment allocations will need to consider additional factors not considered in this study, but our findings suggest that current allocations need reconsideration to support climate adaptation and enhance healthy human nutrition.

Ravindra Bhaghat (2017) analyzed in his research A Geographical Study of Major Crops and Challenges in Indian Agriculture. Agriculture is the backbone of the Indian economy. In India, around $70 \%$ of the population earns its livelihood from agriculture. It still provides livelihood to the people in our country. It fulfills the basic need of human beings and animals. It is an important source of raw material for many agro-based industries. India's geographical condition is unique for agriculture because it provides many favorable conditions. There are plain areas, fertile soil, long growing seasons, and wide variations in climatic conditions, etc. Apart from unique geographical conditions, India has been consistently making innovative efforts by using science and technology to increase production. In this lesson we will discuss various types of farming, cropping patterns and establish their relationship with various geographical factors. We will also discuss some of the major issues and challenges faced by Indian Agriculture.

Musande Maruti Trimbak (2016) Agricultural Productivity in Marathwada Region A Geographical Analysis. Man, s agricultural activities depend on the physical environment in which he lives although he often has tried to minimize the restriction.

Visher (1932) has rightly put forward the theory that a special field of geography concerns itself with the study of the influence of the natural environment on the nature and distribution

of man's activities (Singh and Dhillon, 1987). To make a scientifically viable enquiry into agricultural phenomena, one must pay particular attention to the basic sets of relationships, i.e. those between the intricately related quadruplet complex, viz., the land, the climate, the soils, the water resources and hydrological hazard and agricultural operations, and those between man and the available cultivated area, such a study determines the extent and magnitude of the usefulness of arable land for different agricultural purpose, the number of people engaged in farming and marketing a living out of it, and the types and the number of crops that can be grown on the some field in the course of an agricultural year (Singh Jasbir,1974).

\section{INDIAN AGRICULTURE: AN OVERVIEW}

Indian agriculture depends mainly on the monsoons which are seasonal. There is much uncertainty, both in amount and periodicity of rainfall. The success or failure of Indian agriculture is at the mercy of the monsoons. Since agriculture is a major component of the Indian economy, it depends still on rainfall. If there is any scarcity in the rainfall, it affects a large section of our people.

The urgent need of the times is to increase food production because the annual increase in population is 
17 million and to meet the needs of the additional population, greater importance should be given to the dry land agriculture. In India, there is great scope to increase the productivity of dry land by adopting suitable cultivation techniques, depending upon the conditions prevailing in each region.

\section{TELANGANA AGRICULTURE: AN OVERVIEW}

Telangana agriculture is the means of livelihood for 65 per cent of the state population. The share of agriculture in the state GDP is around 16 percent, which is higher than the national average (12.3 per cent). Telangana is also the first state in the country to come up with a separate budget for agriculture. Telangana has 14.3 million ha of cultivable area, nearly 85 percent of which is now exclusively dependent on rainfall. Even after the development of irrigation to its maximum potential under a big push to irrigation in the immediate future, about 75 percent of the cropped land would remain rainfed. Production from these areas will however be greatly affected by the irregularity of the monsoons, as total rainfall fluctuates widely between years and there are unpredictable variations in the monsoon onset, continuity, and withdrawal of the monsoon.

Precipitation often occurs at such high rates of intensity that a substantial runoff occurs, reducing the potential for infiltration of water into the soil and increasing the danger of soil erosion and crop damage on heavy soils due to inadequate drainage.

Furthermore, the risk of crop failures due to the vagaries of rainfall reduces the individual farmer's willingness to invest in costly inputs and better crop care. In these circumstances, farmers continue to practice low-cost traditional farming methods, and as a result, overall production from rain-fed areas remains generally low, unstable, and stationary, much land lies seasonally fallow due to lack of drainage, inadequate infrastructure, or reluctance on the part of farmers to invest in new technologies - consequently, most rain-fed cultivation is largely subsistence-oriented, and many farmers are struggling for survival. Nevertheless, by virtue of the very large areas involved, these lands contribute 42 percent of the total food grain production of the state. Improvement for the overall social and economic upliftment of many millions of the farming families is however urgently needed. Yet the state has a favorable landscape for agriculture as 65.7 per cent of the total geographical area is under cultivation of crops. The state ranks sixth in the country regarding the cultivation of sugarcane. It contributes 6 percent of the agricultural production of the country. About 75 per cent of the total geographical area of the state is suitable for agriculture. Fertile soils and the presence of 10 agro-climatic zones make Telangana produce a rich variety of agricultural and horticultural crops. The state ranks among the major producers of maize, coarse cereals, sugarcane, pulses, and sunflower in the country.

\section{Agricultural Crops in Nalgonda District}

Agriculture is considered one of the primary occupations for the inhabitants of the Nalgonda district. It plays a pivotal role in dominating the economic, social 9 and cultural life of the people in the Nalgonda district. There are predominant food crops in agriculture and mixed cropping, usually practiced in the same field to ensure some production during unfavorable weather conditions. Most of the people in Nalgonda district is involved in growing crops, especially in rural areas. Agriculture in the Nalgonda district has occupied around $75 \%$ of land for agricultural cultivation. The Kharif crops of Nalgonda district comprise millets, paddy (rice), maize, moong (pulses), groundnut, red chilies, cotton, soybean, sugarcane, and turmeric. It is also known as the autumn harvest as it is cropped with the beginning of the first rains in the month of July. The major Rabi crops of the district are jowar, sunflower and grams. Rice and jowar are the food crops harvested by the farmers and sugarcane and coconut are their commercial crops. Due to various socioeconomic factors, the landholdings are small fragmented, and unfit for modern techniques of agriculture. In the Nalgonda District agriculture is mostly dependent on rainfall which is highly variable in time and space.

The district agriculture has been not implemented on time treatment by the Government. It still suffers from a lack of infrastructure. This has led to frustration and disappointments among the farmers. There is a mass exodus of people from rural to urban areas, in the district, in search of jobs. The district has a high potential for agricultural production, however, and agricultural products include raw silk, in which the district has the highest production range among all other districts of Telangana.

\section{STATEMENT OF THE PROBLEM}

Farming is both a way of life and a principal means of livelihood for 65 per cent of the Telangana's population of nearly 60 million. The state is one of the developing 
areas of the country where most of the people depend on agriculture for their livelihood. Telangana's economy is agriculture-based. Farming traditionally has been viewed as a source of subsistence living and livelihood by the growing of food crops, meeting the food requirements of the farming family. This attitude of the farming community has drastically changed and the farmers in large numbers have migrated to towns and cities for earning high wages and for easily meeting the other requirements of the Farmers have also become, in several thousands, entrepreneurs by integrating animal husbandry, dairy, poultry, fisheries, apiculture, sericulture, and floriculture with crop farming for better living. This has also helped them with self-employment and security and has raised their socio-economic status of the farmers and rural people. In these different ways, farmers could also attain their livelihood security. The farmers of Telangana district are found to depend on crop production for their livelihoods in addition to dairy farming, sheep rearing, small businesses, and other income-generating activities such as salaried employment and wage labour. Small farmers of the district are more diversified and work a combination of enterprises for their livelihoods as compared to medium and large farmers. The combination of crop production, dairy farming, and other economic activities is for maximizing income and hence such a combination is preferred by the people of the district. The agricultural crops have had different problems such as wildlife animals from the forests, lack of irrigation, irrigation infrastructure, marketing and storage facilities, and the dominant role of brokers and middlemen depressing farmers from fetching remuneration prices for their products. Irregular water supply and sugar industries are away from the district. The district agriculture is however backward and traditional when compared to other districts of the state and the other states. It suffers from low productivity, which is mainly caused by the poverty of farmers. Capital investment in agriculture is low and the pace of modernization is also very slow. So, these are the problems which are existing in the study area. Nalgonda district has witnessed remarkable growth and change in irrigation through the Watershed Development Programme, tourism of the pilgrims, and many other anthropogenic activities since its inception as in many other districts of the State of Telangana.

This has therefore resulted in increased land utilization and changes that have occurred in the status of agricultural crops in the district for planning for the future of the agricultural land uses. The agricultural crops have had different problems such as wildlife animals from the forests, lack of irrigation, irrigation infrastructure, marketing and storage facilities, and the dominant role of brokers and middlemen depressing farmers from fetching remuneration prices for their products. Irregular water supply and sugar industries are away from the district. The district agriculture is backward and traditional. It suffers from low productivity, which is mainly caused by the poverty of farmers. Capital investment in agriculture is low and the pace of modernization is also very slow. So, these are the problems which are mentioned in the study area.

The study reported here is concerned about three themes and they are:

- Crops and cropping patterns of the district in time and space.

- Crop ranking, crop concentration and crop diversification towards understanding the crop combination regions of the district; and

- Agriculture and socio-economic changes in the district.

\section{OBJECTIVES OF THE STUDY}

The objectives of the study are:

- To examine and understand the nature and extent of major agricultural crops in different seasons and their patterns in the Nalgonda district of Telangana, India.

- To assess the (positive, increasing, and negative, declining) in various but particularly in some very dominant crops as well as inland, farm, livestock,

- To appreciate the existing and the likely future problems of agriculture and cropping in the study area; and

- To assess the social-economic changes and impacts of agriculture of the study area towards recommending measures that would make such impacts positive for the development of the study area.

\section{RESEARCH METHODOLOGY AND ANALYSIS}

In any research, a proper methodology must be adopted to devise the ways and means for the collection of data from farmers regarding major agricultural crops. The present study envisages a collection of relevant and reliable data from the primary (farmers) and secondary (documentary and research) sources related to area 
under crops, spatial distribution of crops, trends in the patterns of cropping, and the social, economic, and cultural impacts on the crops. The secondary data regarding the topic of research have been collected from different sources. Such sources of data for the current research include documentary reports from the Department of Agriculture and particularly in the selected manuals at statistics offices, Watershed Department, Land Use Board and so on. Maps have been collected from 16 the Natural Resources Data Management System of Nalgonda district and Survey of India (Figure 1).

The FIVE very important components of the methodology adopted in the study are:

- Field survey (primary data - questionnaire survey).

- Collection of documented data (secondary data documentary from the departments of agriculture and other Development agencies).

- Statistical approaches (simple frequency and percentage analysis, regression analysis, and compounded annual growth rates). Crop ranking, crop concentration and crop diversification indexes.
- Analysis and interpretation of data from farmers of

- the study area (Nalgonda District).

- Library research to assemble ideas for the thesis and build a background for understanding the problem of analysis in the study through literature review.

The sources of primary data are the two manuals stratified-randomly picked farmers from the study area, with a distribution among the villages as follows:

\section{Kethepalli Mandals 100 farmers}

They have been chosen in a 'snowballing' sampling from 13 villages spread across the mandalin the district with due representation for this Mandal only. A questionnaire survey using a custom-designed questionnaire has been conducted with the sample farmers, after a pilot study and revision of the questionnaire. Free associational interviews with farmers have been conducted either at their homes or at work. An Excel database has been created to run the statistical analyses, develop graphical representations. SPSS package has been used in the analysis of data, particularly the simple frequency and percentage analysis. The details of the village wise crop ranking in Kethapalli Mandal is given in table 1.

Table 1. Village wise crop ranking in Kethapalli Mandal.

\begin{tabular}{|c|c|c|c|c|c|c|c|c|c|c|c|}
\hline Sr. & Village names & Nam & f the $\mathrm{Cr}$ & ps and ra & king vill & e wise $\mathrm{i}$ & Kethapall & landal & & & \\
\hline & & Rice & Maize & $\begin{array}{c}\text { Cereals, } \\
\text { millets }\end{array}$ & pulses & $\begin{array}{l}\text { Food } \\
\text { grains }\end{array}$ & $\begin{array}{l}\text { Ground } \\
\text { nuts }\end{array}$ & $\begin{array}{l}\text { Soy- } \\
\text { bean }\end{array}$ & $\begin{array}{l}\text { Oil- } \\
\text { seeds }\end{array}$ & $\begin{array}{l}\text { Sugar } \\
\text { cane }\end{array}$ & $\begin{array}{c}\text { Cotto } \\
\mathrm{n}\end{array}$ \\
\hline 1 & Bheemavaram & 3 & 1 & 4 & 1 & 3 & 13 & 3 & 2 & 5 & 9 \\
\hline 2 & Bondapalem & 7 & 3 & 3 & 9 & 12 & 12 & 4 & 12 & 6 & 5 \\
\hline 3 & Bopparam & 4 & 2 & 2 & 2 & 11 & 1 & 9 & 11 & 7 & 7 \\
\hline 4 & cherukupalle & 9 & 8 & 1 & 5 & 10 & 8 & 10 & 10 & 8 & 3 \\
\hline 5 & Gudiwada & 10 & 12 & 9 & 13 & 6 & 3 & 5 & 7 & 3 & 8 \\
\hline 6 & Inpamula & 5 & 13 & 11 & 10 & 7 & 7 & 6 & 5 & 4 & 6 \\
\hline 7 & Ippala Gudem & 11 & 9 & 12 & 11 & 8 & 10 & 11 & 13 & 13 & 4 \\
\hline 8 & kasangode & 13 & 10 & 13 & 6 & 9 & 6 & 12 & 6 & 2 & 1 \\
\hline 9 & kethipalle & 1 & 11 & 10 & 3 & 2 & 4 & 1 & 8 & 1 & 2 \\
\hline 10 & Koppoli & 2 & 7 & 8 & 4 & 1 & 5 & 2 & 1 & 10 & 10 \\
\hline 11 & Korlapahad & 6 & 5 & 7 & 7 & & 9 & 7 & 9 & 12 & 13 \\
\hline 12 & Thungathurthy & 8 & 6 & 6 & 8 & 4 & 11 & 8 & 4 & 11 & 11 \\
\hline 13 & Uppalaphad & 12 & 4 & 5 & 12 & 5 & 2 & 13 & 3 & 9 & 12 \\
\hline
\end{tabular}

Source: Kathapalli mandal census 2021

The CAGR has been calculated using the online CAGR calculator. GIS has been used as the mapping tool, 17 even as image analysis of the district has been borrowed from the Telangana State Remote Sensing Applications Centre, Hyderabad.

\section{The statistical analyses briefly are}

Crop Ranking, Crop Concentration and Crop Diversification Indices have been computed using area under different and major crops in the district and its mandals and the methods devised by Bhatia (1965) have been used in the concentration and diversification analysis. Extensive library research has been carried out by the scholar for assembling ideas for the thesis as well as a review and appraisal of literature from India and abroad. Furthermore, various journals of research publications and magazines have also been referred to in the assembly 
of ideas and corroborative research materials. Secondary information such as the rainfall and other climatic data has been collected from the Department of Meteorology. Field visits have been made on several occasions for collecting primary data through face-to-face interviews, schedulebased interviews, observations and discussions These visits based interviews, observations and discussions. These visits have however provided for firsthand data and information on farming.

Changes in cropping pattern in Telangana: Food crops consisting of cereals, coarse cereals, pulses, and other food crops occupy lion share in total cropped area in the State. Research studies on State's cropping pattern reveal that more than one-third area was food crops during the period. Cropping pattern from the 2016 onward shifted towards non-food crops in the State. Of the total cropped area of 48 lakh hectares in 2011-12, around 71 percent was under food crops and 29 percent was under non-food crops. However, the share of food crops increased to 58 percent and the share of a nonfood crop to 42 percent during the year 2014-15. Even in absolute terms area under food crops came down from 33.98 lakh hectares in 2001-02 to 26.13 lakh hectares in 2014-15. later gradually increased till 2021.This indicates that area under food crops is increasing in both absolute and relative terms and the cropping pattern is shifting towards non-food crops.

\section{KethePalle Mandal - Nalgonda}

List of all towns and Villages in KethePalle Mandal of Nalgonda district, Telangana. Each village name and agricultural Ranking was given below in Table 2.

Table 2. List of towns and Villages in KethePalle Mandal with their administrative division and population.

\begin{tabular}{llll}
\hline Sr. & \multicolumn{1}{c}{ Villages } & $\begin{array}{c}\text { Administrative } \\
\text { Division }\end{array}$ & Population \\
\hline 1 & Bheemavaram & KethePalle & 3,636 \\
2 & Bonda Palem & KethePalle & 2,059 \\
3 & Bopparam & KethePalle & 1,600 \\
4 & CherukuPalle & KethePalle & 3,087 \\
5 & Gudiwada & KethePalle & 3,558 \\
6 & Inpamula & KethePalle & 3,484 \\
7 & Ippala Gudem & KethePalle & 888 \\
8 & Kasangode & KethePalle & 2,026 \\
9 & Kethepalle & KethePalle & 8,193 \\
1 & Koppole & KethePalle & 2,947 \\
1 & KorlaPahad & KethePalle & 1,986 \\
1 & Thungathurthy & KethePalle & 2,828 \\
1 & UppalaPahad & KethePalle & 1,241 \\
\hline
\end{tabular}

Source: Statistical Report-Nalgonda District 2021
Frequency analysis is particularly useful for describing discrete categories of data having multiple choices or yes/no response formats. This analysis involves constructing a frequency distribution. The only technical requirement of the frequency analysis is that the categories of response be mutually exclusive and exhaustive. This means that the same observation cannot be counted as belonging to more than one response category. The frequency analysis must be exhaustive in the sense that all respondents must fit into a category. The tables so generated are numerous, and hence only a select number of tables are included in the text while others are interpreted so as to show the variations therein.

Regression is the measure of the average relationship between two or more variables in terms of the original units of the data. The term regression analysis refers to the methods by which estimates are made of the values of a variable from knowledge of the values of one or more other variables and to the measurement of the errors involved in this estimation process. Regression analysis is a statistical device with the help of which we can estimate (or predict) the unknown values of one variable from known values of another variable. The variable which is used to predict the variable of interest is called the independent variable or "explanatory" variable and the variable we are trying to predict is called the dependent variable or "explained" variable.

The independent variable is denoted by $X$ and the dependent variable by $\mathrm{Y}$. The equation is quite simply: $\mathrm{Y}$ $=\mathrm{a}+\mathrm{Xb}$ where $\mathrm{Y}$ is the dependent variable, $\mathrm{X}$ is the independent variable, ' $a$ ' is the intercept and ' $b$ ' is the slope which determines the rate of change.

Compound annual growth represents, in general terms, growth over a period of years, with each year's growth added to the original value. Sometimes called compound interest, the compound annual growth rate 18 indicates how much income the investment is generating when you reinvest the returns. It is especially useful when your investment experiences significant fluctuations in growth from year to year, since a volatile market means an investment may see large returns one year, losses the next and then more moderate growth another year. It can be used not only to evaluate the performance of the investment, but to compare returns on different types of investments, such as stocks and bonds or stocks and a savings account. Business owners may use the CAGR to analyze the performance of a variety of business 
measures, including market share, expense, income and customer satisfaction levels. Note that the CAGR is an imaginary number used to describe the rate an investment would have grown if it had grown at a steady rate every year. There are some years where an investor/businessman received a better return than his/her final number and some years where she/he got a worse return. She/he is rarely ever going to get the same return every year.

The social-economic changes and impacts of agriculture of the study area towards recommending measures that would make such impacts positive for the development of the study area.

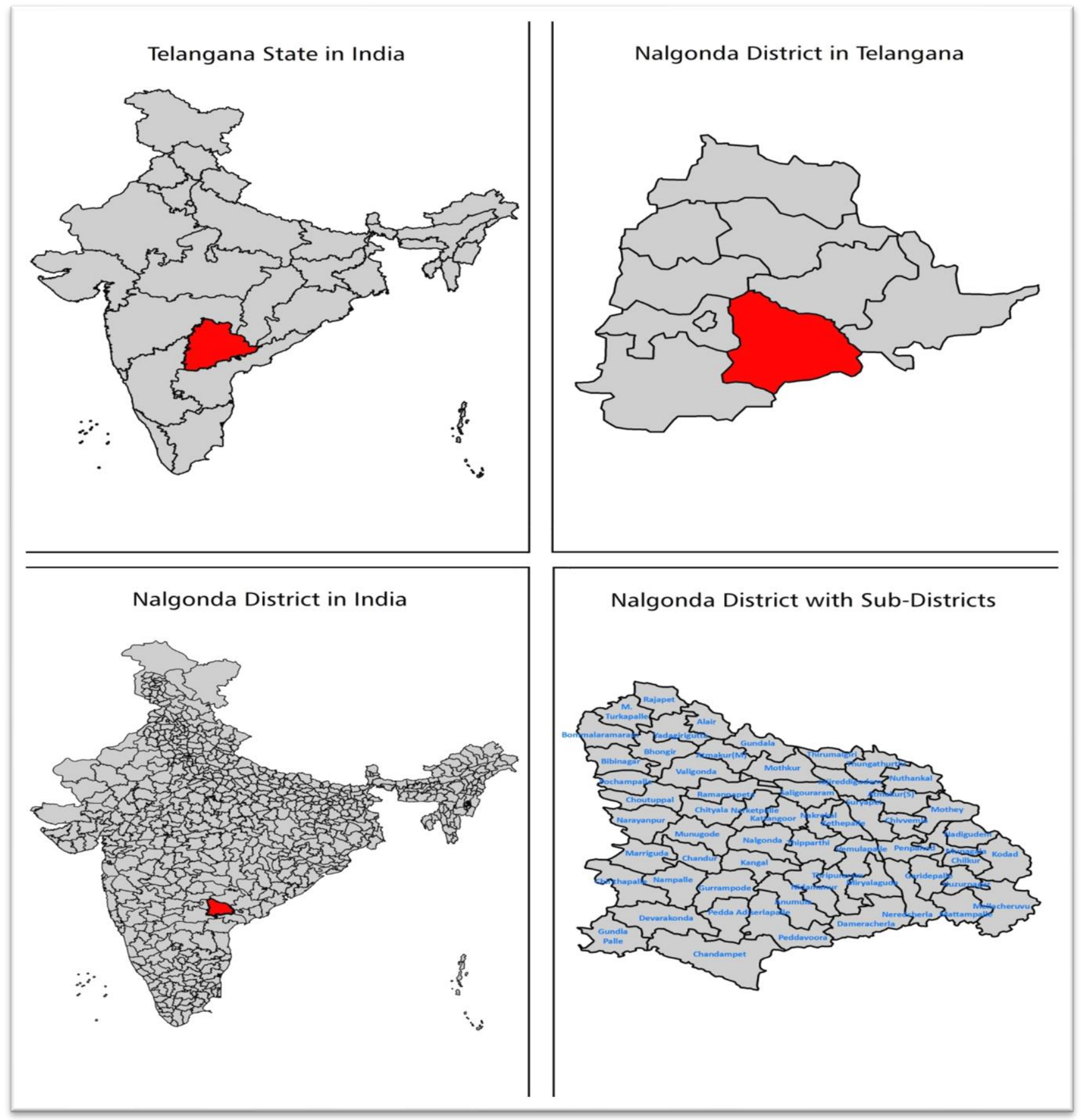

Figure 1. Location map of Nalgonda District

(Source: Statistical Report-Nalgonda District 2021) 
Kethapallimndal people socio-economic status is growing from last five years, there is tramandas change. They have constructed buildings; they started life in hurts, but now extraordinary houses, using AC, washing machine, laptops internet sources, food also having qualitative nutrition food.

This Mandal is working towards agricultural development, comparing to last five years, agricultural development is sustainable growing. Government also assisting through Schemes like Raithubandu, Raithubarosa. Almost the Mandal is developing, the present status is $80 \%$ developed from $2016-2021$.

\section{REFERENCES}

Amor, V. M., Gupta, D.A. and Loof, R. (2002). Application of GIS and crop model in estimating water productivity. Journal of Agricultural Water Management, 54, 205-225.

Aregay, F.A. (2012). Impact of irrigation on fertilizer use decision of Farmers in China: A case study in Weihe river basin. Journal of Sustainable Development, 15(4), 74-81.

Babu, S. and Murali, N. (2014). Factors influencing production of food grains: A study of Tamil Nadu. Southern Economist, 53(4), 5-8.

Barghouti, S., Kane, S., Sorby, K. and Ali, M. (2004). Agricultural diversification for the poor: Guidelines for practitioners. Agriculture and Rural Development Discussion Paper 1. Agriculture and Rural Development Department. The International Bank for Reconstruction and Development, March 4-12.

Bauer, M.W., Gaskell, G., and Allum, N.C. (2000) Quality, quantity and knowledge interests: Avoiding confusions, In Bauer, M.W. and Gaskell, G. (eds.) Qualitative researching with text, image and sound: A practical handbook, London: Sage.

Bhupal, K. and Reddy, R.B. (2014). Agricultural land use pattern in Chandragiri mandal, Andhra Pradesh, India. Journal of International Academic Research for Multidisciplinary. 1(12), 401-417.

Blaikie, N. (2003) Analyzing quantitative data. London: Sage.

Blamurgan, M., Ilanthiryan, A. and Gandhimathi, A. (2013). Agricultural land utilisation of Sweta Nadi basin, Salem district. Proceedings of the
UGC sponsored National Seminar in Maharani's College in Mysore. (January 23-24), 5 to 11.

Brannen, J. (2005) Mixing Methods: The entry of qualitative and quantitative approaches into research process. The International Journal of Social Research Methodology, 8(3): 173-185.

Creswell, J. W. (2009) Mapping the field of mixed methods research. Journal of Mixed Methods Research, 3, 95-108.

Dorjee, K., Broca, S. and Pingali, P. (2003). Diversification in South Asian agriculture: Trends and constraints, Agricultural and Development Economics Division, The Food and Agriculture Organization of the United Nations, ESA Working Paper No. 03-15, July, 2.

Gomatee, N. I. H. (2012). Pattern of crop concentration and diversification in Upper Ganga Yamuna Doab, International Journal of Innovative Research and Development, 1(5), 481-496.

Karale, M.R., Adavitote, S.C. and Thombare, P.Y. (2012). Region wise Requirement of water resources for agriculture in drought prone area of parner tahsil, district, Ahmednagar: A geographical analysis, Indian Stream Research Journal, 1(V), $12-14$

Martínez, S. and Mollicone, D. (2012). From Land Cover to Land Use: A Methodology to Assess Land Use from Remote Sensing Data, Remote Sensing, 4, 1024-1045.

Mohanthy, D. (2014). Why is recent food inflation in India so persistent? Southern Economist, 52(12), 49-51.

Muhammad, A. (2011). Mastery over geography and the rise of social development: A case study of the canal irrigation system of the west Punjab during colonial India. Academic Research International, 1(3), 65-71.

Patton, M.Q. (2002). Qualitative evaluation and research methods, 2nd edition, London: Sage.

Ramesh, S. (2014). Socio-economic conditions of women in agricultural labourers: A study in Tiruvarur, Southern Economist, 53(9), 12-14.

Todkari, G.U. (2012). A study of crop combination in Solapur district of Maharashtra. Journal of Crop Science, 3(1), 51-53. 
Publisher's note: EScience Press remains neutral with regard to jurisdictional claims in published maps and institutional affiliations. (c) (1)

EY Open Access This article is licensed under a Creative Commons Attribution 4.0 International License, which permits use, sharing, adaptation, distribution and reproduction in any medium or format, as long as you give appropriate credit to the original author(s) and the source, provide a link to the Creative Commons license and indicate if changes were made. The images or other third-party material in this article are included in the article's Creative Commons license, unless indicated otherwise in a credit line to the material. If material is not included in the article's Creative Commons license and your intended use is not permitted by statutory regulation or exceeds the permitted use, you will need to obtain permission directly from the copyright holder. To view a copy of this license, visit http://creativecommons.org/licenses/by/4.0/.

(C) The Author(s) 2020. 